\title{
Interferon- $\gamma$ receptor-1 gene promoter polymorphisms and susceptibility for brucellosis in Makkah region
}

\author{
AB Ismael ${ }^{1,2}$, A Mergani ${ }^{1,3}$, A Salim $^{4}$, S Mostafa ${ }^{4,5}$, I Alkafaween ${ }^{4}$
}

1. Department of Medical Biotechnology, Faculty of Applied Medical Sciences, Taif University, Turrabah, 21995, KSA.

2. Department of Animal Medicine, Faculty of Veterinary Medicine, Zagazig University, Zagazig 44519, Egypt.

3. Department of Human Molecular Genetics, National Cancer Institute (NCI), Gezira University, Sudan.

4. Department of Medical Microbiology, Faculty of Applied Medical Sciences, Taif University, Turabah, 21995, KSA.

5. Immunobiology and Immunopharmacology Unit, Animal Reproduction Research Institute (ARRI), Giza, Egypt.

\begin{abstract}
:
Background: Genetic polymorphisms that affect the production levels of certain cytokines and/or their receptors may determine the risk, severity or protection in some infectious diseases like brucellosis.

Objectives: The aim of this study was to investigate the association of certain known Interferon- $\gamma$ Receptor-1 (IFN- $\gamma$ R1) gene promoter polymorphisms and the susceptibility to infection with Brucellosis in Saudi population.

Methods: A cases-control association study was conducted in 69 individuals with human brucellosis and 94 healthy individuals. Genotyping of IFN $-\gamma$ R $1-56 \mathrm{C}>\mathrm{T}$ and IFN $-\gamma \mathrm{R} 1-611 \mathrm{~A}>\mathrm{G}$ polymorphism in both patients and healthy controls was done by PCR- restriction enzyme length polymorphisms (PCR-RFLP) and PCR-confronting two primer pairs (PCR-CTPP) methods and were assessed for potential associations with susceptibility for human brucellosis and their mode of penetrance.

Results: Interestingly, we have designed a PCR-CTPP system to be used for genotyping of IFN- $\gamma$ R1 - 611 A $>$ G polymorphism. The PCR-CTPP is an accurate method for genotyping of SNPs. Moreover, it is time-saving, inexpensive and easy to perform.

Conclusion: Both tested polymorphisms, IFN- $\gamma$ R1 - 56 C $>$ T and IFN $-\gamma$ R1 $-611 \mathrm{~A}>\mathrm{G}$ polymorphism had no role in genetic susceptibility to human brucellosis in the study population. The PCR-CTPP can be used for genotyping IFN- $\gamma$ R1 -611 A $>$ G polymorphism and other types of mutation.
\end{abstract}

Keywords: Brucellosis; susceptibility; IFN- $\gamma$ R1 gene promoter polymorphisms.

DOI: https://dx.doi.org/10.4314/ahs.v18i4.36

Cite as: Ismael AB, Mergani A, Salim A, Mostafa S, Alkafaween I. Interferon- $\gamma$ receptor-1 gene promoter polymorphisms and susceptibility for brucellosis in Makkab region. Afri Health Sci. 2018;18(4): 1157-1165. bttps:// dx.doi.org/10.4314/ahs.v18i4.36

\section{Introduction}

Brucellosis is one of the most common zoonotic diseases in the world that is mainly endemic in Middle East, Africa, Asia and Central and South America and is associated with significant health problems and economic

\section{Corresponding authors:}

Alaa B Ismael \& Adil Mergani,

Department of Medical Biotechnology,

Faculty of Applied Medical Sciences,

Taif University, Turrabah, 21995, KSA,

Email: a.alahmar@tu.edu.sa,

alismael7@gmail.com losses ${ }^{1}$. The etiological agents of brucellosis are Brucella species that are small, Gram-negative, aerobic, facultative intracellular, coccobacilli bacteria and cause undulant fever, endocarditis, arthritis, and osteomyelitis in humans and abortion and temporary infertility in domestic animals ${ }^{2}$. In Saudi Arabia, human brucellosis has emerged as a major public health problem with increasing rates of annual admissions for brucellosis ${ }^{3}$. This increasing in incidence rates of brucellosis had been strongly linked to the uncontrolled importation of potentially infected animals with brucellosis, widespread cattle breeding, and the prevailing habit of ingesting raw milk or its products among the population with a nomadic background ${ }^{4}$. Brucella organisms infect cells of the reticuloendothelial sys-

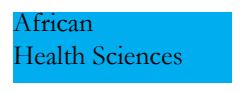

(C) 2018 Ismael et al. Licensee African Health Sciences. This is an Open Access article distributed under the terms of the Creative commons Attribution License (https://creativecommons.org/licenses/BY/4.0), which permits unrestricted use, distribution, and reproduction in any medium, provided the original work is properly cited. 
tem and can be sequestered in at specific locations within the body, such as brain, heart, spleen, joints, liver and bone marrow ${ }^{5}$.

Human protective immune response against Brucella infection depends on cell-mediated immunity involving mainly activated antigen-presenting cells (macrophages, dendritic cells) and $\mathrm{CD}^{+}$and $\mathrm{CD}^{+} \mathrm{T}$ lymphocytes ${ }^{6}$. Upon encounter with Brucella antigens, antigen presenting cells (APC) produce cytokines such as Interleukin (IL)-23, IL-1 $\beta$, IL-18, IL-12 and TNF via the stimulation of pattern recognition receptors, including Toll-like receptors ${ }^{7}$. Type-1 helper T (Th1) cells and natural killer $(\mathrm{NK})$ cells express receptors for these cytokines and produce Interferon- $\gamma$ (IFN- $\gamma$ ) in response to IL-12 or IL-23, which can be enhanced by IL-1 $\beta$ and IL-18. The IFN- $\gamma$ is a pleiotropic cytokine playing a central role in type-1 immunity against intracellular pathogens such as Brucellosis, Mycobacteria and Salmonellae and up-regulates macrophage killing mechanisms by induction of superoxide anions and hydrogen peroxide ${ }^{8}$. The IFN- $\gamma$, in turn, binds to the IFN- $\gamma$ receptor (IFN- $\gamma \mathrm{R}$ ) which is made up of $\mathrm{a}$ and $\mathrm{b}$ subunits, both of which are integral membrane proteins and present on nearly all cell types. The $\alpha$ sub-unit (encoded by the gene IFN- $\gamma$ R1) plays a critical role in ligand binding, receptor trafficking, and signal transduction ${ }^{9}$. APCs, including monocytes, macrophages and Dendritic cells (DCs), are activated by IFN- $\gamma$ to produce increased levels of IL-12 and to enhance both antigen presentation and bactericidal activity ${ }^{10}$. Further, IFN- $\gamma$, depending on cell type, can block proliferation and induce apoptosis of infected cells or enhance expression of cell surface molecules such as HLA Class I and II, CD54 and CD64. The IFN- $\gamma$ R is comprised of two ligand-binding IFN- $\gamma \mathrm{R} 1$ chains associated with two signal-transducing IFN- $\gamma$ R2 chains. Binding of IFN- $\gamma$ to its receptor induces receptor oligomerization and activation of the receptor-associated Janus kinases, JAK1 and JAK2, by trans-phosphorylation.

The JAKs phosphorylate the tyrosine 440 that is part of the signal transducer and activator of transcription protein1 (STAT1) docking site in the intracellular domain of the IFN- $\gamma$ R1 and subsequent STAT1 phosphorylation. Phosphorylated STAT1 dissociates from the receptor, dimerizes and translocates to the nucleus, where it regulates the expression of IFN- $\gamma$ responsive genes direct- ly or indirectly via the induction of other transcription factors such as IRF1, IRF7 and CIITA ${ }^{11,12}$. STAT1 is the main mediator of IFN- $\gamma$ responses although, IFN- $\gamma$ was reported to induce STAT3 or STAT5 phosphorylation in a few other cell types ${ }^{13}$.

In the IFN- $\gamma$ R1 several amino acid substitutions have been reported that abrogate IFN- $\gamma$ signaling. These substitutions can lead to a null phenotype and enhanced susceptibility to infection by low pathogenic mycobacteria and salmonellae, a disorder known as Mendelian Susceptibility to Mycobacterial Diseases (MSMD) ${ }^{14,15}$. Several potentially functional single nucleotide polymorphisms (SNPs) have been identified in the human IFN- $\gamma$ R1 gene promoter. Few studies investigated the association between IFN- $\gamma$ R1 gene polymorphisms and risk of infectious diseases. Previously, we studied the protective role of TNF- $\alpha-857 \mathrm{C} / \mathrm{T}$ and $\mathrm{TNF}-\alpha-308 \mathrm{~A}$ polymorphism against human brucellosis ${ }^{16}$. This study aimed mainly (i) to determine the frequency of the selected polymorphisms located in IFN- $\gamma$ R1 gene promoter in patients and healthy individuals selected from the general population of Makkah Region, (ii) to determine the association of IFN- $\gamma$ R1 gene promoter polymorphisms and genetic susceptibility to Brucellosis among the selected population and (iii) to develop a PCR-confronting two primer pairs (PCR-CTPP) system to be used for genotyping of IFN- $\gamma$ R1 - 611 A $>$ G polymorphism.

\section{Materials and methods}

\section{Study design and selection of patients and their con- trols}

A case-control prospective study was carried out to investigate the impact of IFN- $\gamma$ R1 polymorphisms on resistance/susceptibility to human brucellosis disease among Saudi population at Makkah region. All patients who had been admitted to general hospitals during the period of study subject selection and were presenting with clinical signs and symptoms (e.g., fever, malaise, night sweating, weakness, weight loss, myalgia, splenomegaly, lymphadenophathy and arthralgia), suggestive of active brucellosis were examined by specialists and confirmed by a positive serological test in a single high titers $(\geq 1 / 160)$ of Standard Agglutination Test (SAT) and/or positive blood cultures. A group of 69 confirmed patients with active Brucellosis were selected, after their acceptance, to participate in the study. Twenty-four $(34.8 \%)$ of the patients were females and $45(65.2 \%)$ were males. Their age varied 
from 12 to 77 years with a mean of $42 \pm 22.17$ years. The patients were from different nationalities that were Saudi Arabian 52 (75.4\%), Sudanese, 7 (10.1\%), Egyptian 4 (5.8\%), Pakistanian, 4 (5.8\%) and Indian, 2 (2.95\%). A group of controls composed of 94 healthy individuals with no history of brucellosis and were matched for geographic area, age and sex and had the same risk of exposure for brucellosis with SAT $\leq 1 / 80$. They were selected for the study after accepting to participate in the study. Blood (EDTA tube and plain tube) samples were collected from all participants. The protocol was approved by the Hospital Ethics Committee and written informed consent was obtained from all participants.

\section{Mutation analysis of IFN- $\gamma$ R1 gene polymorphisms in patients and control groups}

Two polymorphisms located in the promoter of IFN- $\gamma$ R1 gene were selected for evaluation of their relation to susceptibility for human brucellosis study population. Both polymorphisms are transition mutation. The first is a transition replacement of cytosine to thiamin at position -56 (rs2234711) in respect to transcription site. While the other, is transition replacement of adenine for guanine at position - 611 (rs1327474). Genomic DNA was extracted from peripheral blood leukocytes using standard methods as described by the manufacture (Micromix660 DNA extraction kit, Talent, Italy). The quality of the isolated DNA had been checked by electrophoresis on $1 \%$ agarose gel, quantitated spectrophotometrically and stored at $-20^{\circ} \mathrm{C}$ till further use.

Screening of IFN- $\gamma$ R1 -56 T > C polymorphisms by Restriction Enzyme Length Polymorphisms (RFLP) A 306 bp DNA fragment flanking the polymorphic site was PCR amplified using 100ng of genomic DNA in a total reaction volume of $30 \mu \mathrm{l}$ using the primer pair: IFN- $\gamma$ R-56 F: 5`- TCCTCCCACACCCAgAAgTCC -3 and IFN- $\gamma$ R -56 R: 5 - gCggTgCCCATCTCAgCCCT -3 . PCR condition as initial temperature $95 \mathrm{C}^{\circ}$ for $5 \mathrm{~min}$ ute, flowed by 35 cycles of $94 \mathrm{C}^{\circ}$ as melting temperature for one minute, $60 \mathrm{C}^{\circ}$ as annealing temperature for one minute and $72 \mathrm{C}^{\circ}$ as extinction temperature, then final prolongation step at $72 \mathrm{C}^{\circ}$ for 5 minutes. The transition replacement of cytosine to thiamin in position -56 create a new restriction site for Eco 47Щ. In a total volume of $15 \mu \mathrm{l}, 5 \mu \mathrm{l}$ PCR products was digested overnight with $1 \mu \mathrm{l}$ Eco $47 Щ$ enzyme and mixed with Buffer 3 10x, BSA
$50 \mu \mathrm{g}$ and demonized water. The Digested DNA were mixed with $5 \mu \mathrm{l}$ loading dye before electrophoresis in $2 \%$ agarose gel and the gels were stained in $1 \mu \mathrm{g} / \mathrm{ml}$ ethidium bromide solution for 10-15 minutes and visualized with UV light under GDS.

\section{Interpretation of digestion reaction electrophoresis profiles}

The genotype was assigned according to the length of obtain fragments. Complete cleavage 306 bp PCR product into the 186 and $120 \mathrm{bp}$ fragments is characteristic profile of the homozygote mutant allele (CC), incomplete cleavage into $306 \mathrm{bp}, 186 \mathrm{bp}$ and $120 \mathrm{bp}$ is of the heterozygote (TC). While absence of digestion is a characteristic of the homozygote wild (TT).

\section{Screening of IFN- $\gamma$ R1 - $611 \mathrm{~A}>\mathrm{G}$ polymorphism by Confronting Two Primer Pairs (PCR-CTPP)}

The principle of PCR-CTPP is based on the fact that: the efficiency of PCR amplification depends on the complete matching of primer sequence at it's 3 'end. Thus, any mismatch at this end of the primer will affect the PCR amplification system. Accordingly, PCR-CTPP genotyping system needs four primers; two common primers flanking the polymorphic site one at each side, but with different length from the polymorphic site ${ }^{17}$. The other two, are allele specific primers and each primer had been designed to be absolutely complementary to one allele sequence specially at the 3 ' end of the primer. We have designed a PCR-CTPP system to be used for genotyping of IFN- $\gamma$ R1 - 611 A > G polymorphism. Four primers were designed for IFN $\gamma \mathrm{R} 1-611 \mathrm{~A}>\mathrm{G}$ polymorphism PCRCTPP genotyping system.

IFN $\gamma R 1$ - 611 OF: 5 - CTAACTCTTggACT'TCACCTgg $-3$

IFN $\gamma$ R1- 611 OR: 5` gCACAAgCgCTgAAggACTTAg $-3$

IFN $\gamma$ R1- 611 A: 5` CAATTCAgTgTCAAATCAgTTTCTT -3

IFN $\gamma$ R1- 611 G: 5 - CTCTTCATgAgAggCTgCTTg -3`

In the presence of the of $\mathrm{A}$ allele at position - 611 in the promoter of IFN- $\gamma$ R1 gene, IFN- $\gamma$ R1- 611 A primer worked to amplify with the primer IFN- $\gamma$ R1- 611OR to give a PCR fragment of $136 \mathrm{bp}$ while in the presence of the $G$ allele at position, the primer IFN- $\gamma$ R1- $611 \mathrm{G}$ worked to amplify with the primer IFN- $\gamma$ R1- 611 OF to give a PCR fragment of $261 \mathrm{bp}$. A third PCR product of 
352bp may be obtained as a result of the IFN- $\gamma$ R1- 611 OF and IFN- $\gamma$ R1- 611 OR. PCR product was electrophoresis in $2 \%$ agarose gel and the gels were visualized with UV light under GDS after being stained in $1 \mu \mathrm{g} / \mathrm{ml}$ ethidium bromide solution for 10-15 minutes.

The genotypes were assigned according to obtained profile; two bands of 352 and 284 bp would be assigned as homozygote $G / G$, Three bands 352, 284 and 136 bp as heteroyzote $A / G$ while two bands of 352 and $136 \mathrm{bp}$ would be assigned as homozygote A/A genotype.

\section{Statistical analysis}

The Statistical Package for the Social Science (SPSS for Windows 14) wasused for statistical analysis. T- Test was used for comparing the distribution of a variable between cases and controls groups. The Chi-square test was applied in comparing of categorical data. The magnitude of association of the polymorphism different genotypes and alleles and susceptibility to Brucellosis in the study population were tested using Cochran - Armitage (CA) trend test and Odd ratios (ORs) and 95\% confidence intervals (CIs) in different genetic models of inheritance were calculated. All P values of less than 0.05 were considered significant.

\section{Results}

In the present study, two transition polymorphisms located in the promoter of IFN- $\gamma$ R1 gene at nucleotides - 56 (replacement of $\mathrm{C}$ by $\mathrm{T}$ ) and - 611(replacement of A by $G$ ) were selected for evaluation of their relation to susceptibility for human brucellosis study population and were genotyped in 69 brucellosis cases and 94 healthy controls. Distributions and genotyping of both polymorphisms in Brucellosis cases and healthy controls groups were done by PCR-RFLP and PCR-CTPP methods as showing in Fig. 1, 2, 3 and 4 respectively. Genotypes frequencies of IFN- $\gamma \mathrm{R} 1-56 \mathrm{C}>\mathrm{T}$ polymorphism in Brucellosis cases were 23 (33\%) CC, 31 (45\%) were CT and $15(22 \%)$ were T'T genotypes while, in healthy control 23 (24.5\%) were CC, 54 (57.4\%) were CT and 17 (18.1\%) were TT. Considering IFN- $\gamma$ R1 - $611 \mathrm{~A}>\mathrm{G}$ polymorphism, Genotypes frequencies in Brucellosis cases were $36(52 \%)$ AA, $25(36 \%)$ AG and $8(12 \%)$ GG genotypes while, in healthy control 49 (51\%) AA, 37 (39\%) AG and $10(10 \%)$ GG. There are no significant differences in genotypes or alleles frequencies of both polymorphisms between Brucellosis cases and healthy controls groups.

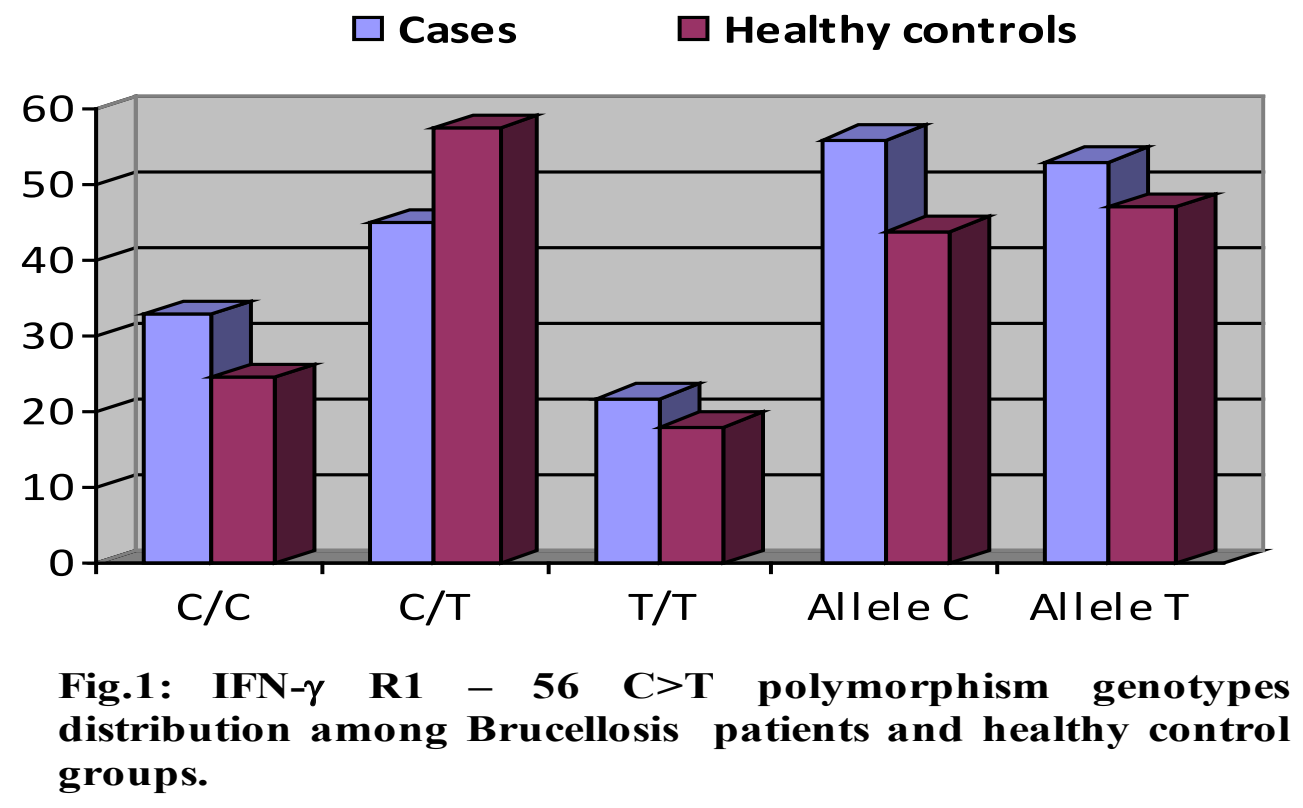




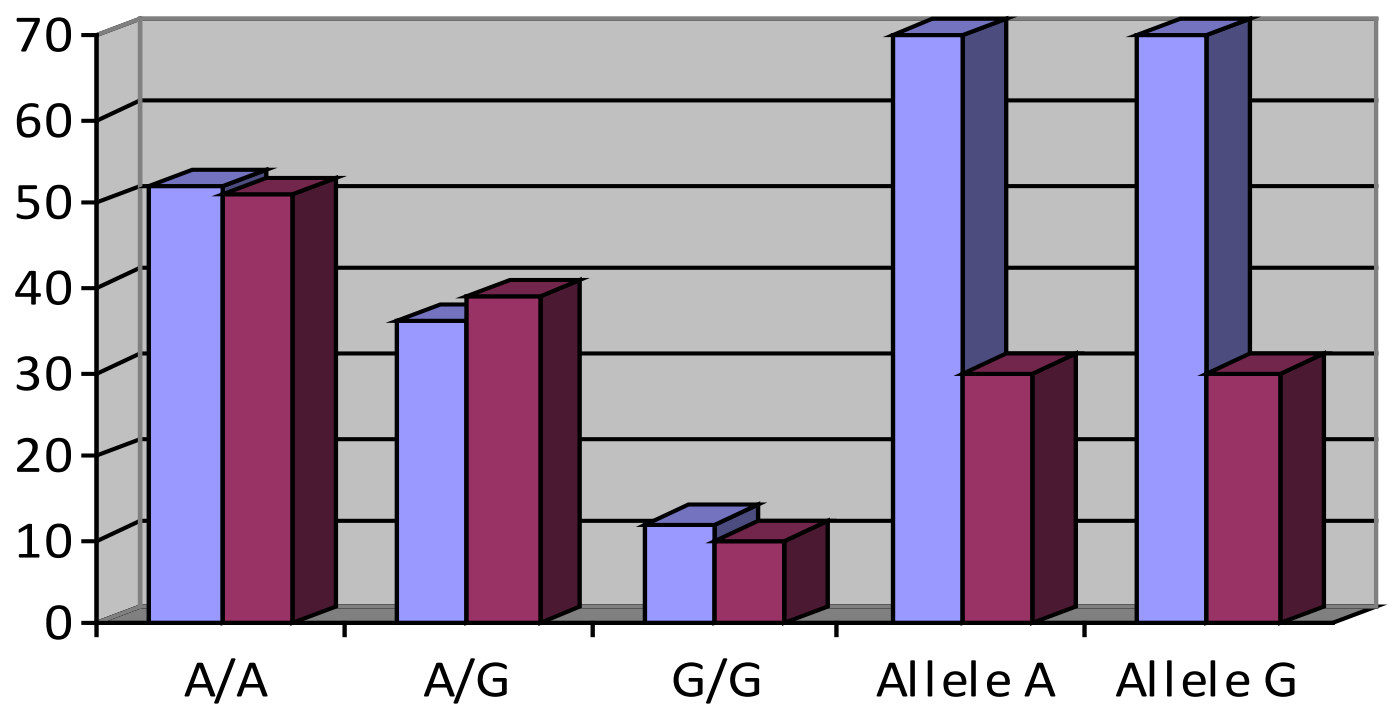

Fig.2: IFN- $\gamma$ R1 - 611 A $>$ G polymorphism genotypes and alleles distribution among Brucellosis patients and healthy control groups.

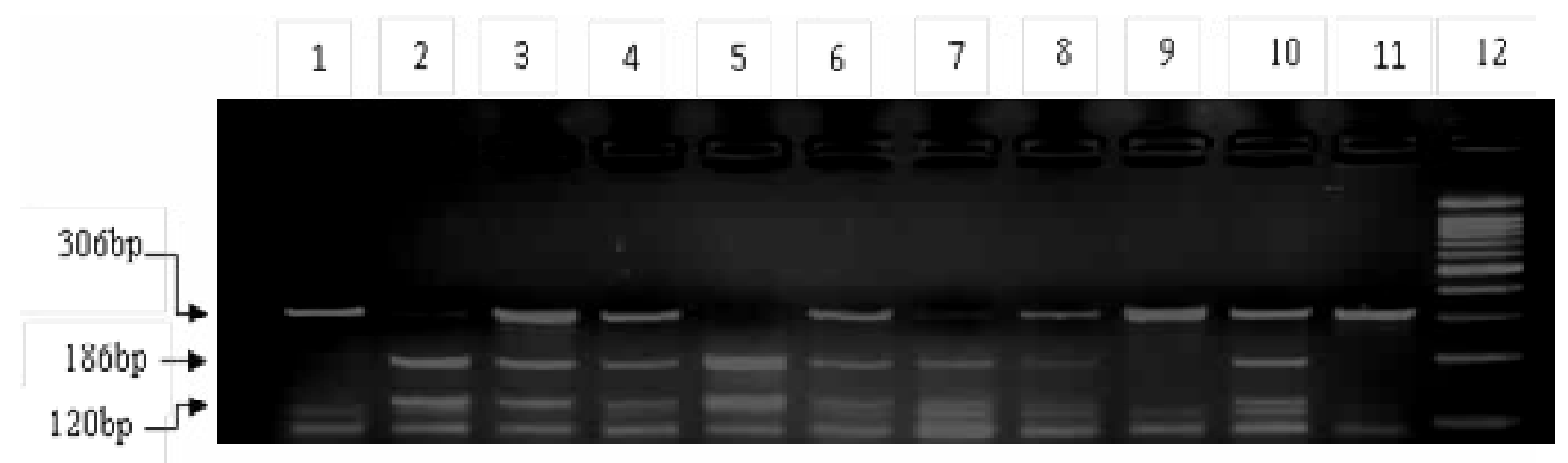

Fig. 3: Genotyping of IFN- $\gamma$ R1 - 56 C $>$ T polymorphism by PCR-RFLP Lanes 1, $9 \& 11$ are homozygous for allele $\mathrm{T}$ and Lanes 2, $5 \& 7$ are homozygous for allele $\mathrm{C}$ while $3,4,6,8$ \& 10 are heterozygous. Lane 12: A 100-bp DNA marker 


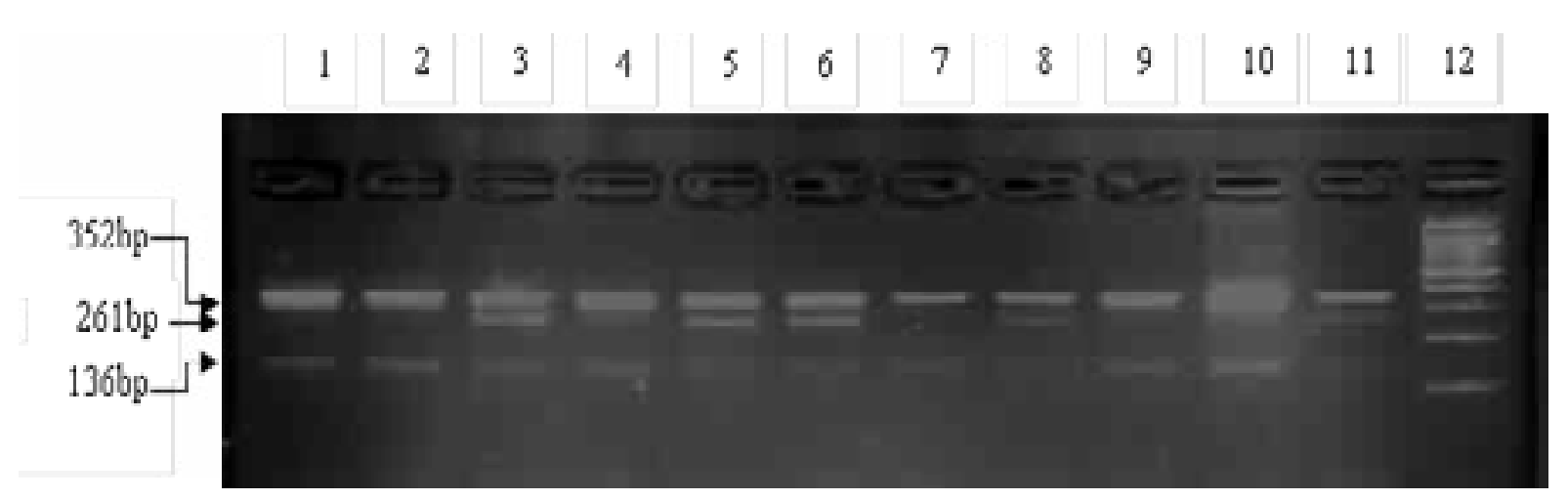

Fig.4: Genotyping of IFN- $\boldsymbol{\gamma}$ R1 - 611 A $>$ G polymorphism by CTPP method Lanes 1, 2, 4, 7, $9 \& 10$ are homozygous for allele $A$ and Lanes 3, 5, $6 \& 8$ are heterozygous while only Lane 11 is homozygous for allele G. Lane 12: A 100bp DNA marker

Associations of both polymorphisms with susceptibility for human brucellosis study population were assessed by Armitage trend test for its penetrance in different genetic models of inheritance; allelic, co-dominant, dominant, over dominant and recessive models (Table 1 and 2). Ac- cordingly, non of the tested models was consistent nor fit penetrance of any of the two polymorphisms. This concluded that both tested polymorphisms, IFN- $\gamma$ R1 $56 \mathrm{C}>\mathrm{T}$ polymorphism and IFN- $\gamma \mathrm{R} 1-611 \mathrm{~A}>\mathrm{G}$ polymorphism had no rule in genetic susceptibility to human brucellosis in study population.

Table 1: Assessment of association of IFN $-\gamma \mathrm{R} 1-56 \mathrm{C}>\mathrm{T}$ polymorphism and Brucellosis patients.

\begin{tabular}{lcccc}
\hline Model & $\begin{array}{c}\text { Brucellosis patients } \\
(\mathbf{n}=\mathbf{6 9})\end{array}$ & $\begin{array}{c}\text { Healthy } \\
\text { control } \\
(\mathbf{n = 9 4 )}\end{array}$ & $\begin{array}{c}\text { P value } \\
\text { (Pearson) }\end{array}$ & Odd ratio (95\% CI) \\
\hline Codominant & $23(33 \%)$ & $23(24.5 \%)$ & 0.469 & \\
$\mathrm{C} / \mathrm{C}$ & $31(45 \%)$ & $54(57.4 \%)$ & & $0.916(0.579-1.400)$ \\
$\mathrm{C} / \mathrm{T}$ & $15(22 \%)$ & $17(18.1 \%)$ & & \\
$\mathrm{T} / \mathrm{T}$ & & & & \\
\hline Allelic effect & 0.56 & 0.53 & & \\
$\mathrm{C}$ & 0.44 & 0.47 & 0.641 & $1.000(0.579-1.400)$ \\
$\mathrm{T}$ & & & & \\
\hline Overdominant & $38(55.1 \%)$ & $40(42.6 \%)$ & & $0.574(0.277-1.188)$ \\
$\mathrm{C} / \mathrm{C}-\mathrm{T} / \mathrm{T}$ & $31(45 \%)$ & $54(57.4 \%)$ & 0.133 & 1.00 \\
$\mathrm{C} / \mathrm{T}$ & & & & \\
\hline Recessive & $54(78 \%)$ & $77(81.9 \%)$ & & 1.00 \\
$\mathrm{C} / \mathrm{C}-\mathrm{C} / \mathrm{T}$ & $17(18.1 \%)$ & 0.561 & $0.795(0.366-1.728)$ \\
$\mathrm{T} / \mathrm{T}$ & $15(22 \%)$ & & & $0.648(0.326-1.288)$ \\
\hline Dominant & & & \\
$\mathrm{C} / \mathrm{C}$ & $46(67 \%)$ & $71(75.5 \%)$ & & \\
$\mathrm{C} / \mathrm{T}-\mathrm{T} / \mathrm{T}$ & $23(33 \%)$ & $23(24.5 \%)$ & 0.214 & \\
\hline
\end{tabular}


Table 2: Assessment of association of IFN- $\gamma \mathrm{R} 1-611 \mathrm{~A}>\mathrm{G}$ polymorphism and Brucellosis patients.

\begin{tabular}{|c|c|c|c|c|}
\hline Model & $\begin{array}{c}\text { Brucellosis patients } \\
\qquad(\mathrm{n}=69)\end{array}$ & $\begin{array}{l}\text { Healthy } \\
\text { control } \\
(\mathrm{n}=96)\end{array}$ & $\begin{array}{c}\text { P value } \\
\text { (Pearson) }\end{array}$ & Odd ratio $(95 \% \mathrm{CI})$ \\
\hline \multicolumn{5}{|c|}{ Co-dominant } \\
\hline $\mathrm{A} / \mathrm{A}$ & $36(52 \%)$ & $49(51 \%)$ & \multirow{3}{*}{0.260} & \\
\hline $\mathrm{A} / \mathrm{G}$ & $25(36 \%)$ & $37(39 \%)$ & & \\
\hline $\mathrm{G} / \mathrm{G}$ & $8(12 \%)$ & $10(10 \%)$ & & $0.999(0.632-1.644)$ \\
\hline \multicolumn{5}{|c|}{ Allelic effect } \\
\hline A & 0.70 & 0.70 & & \\
\hline $\mathrm{G}$ & 0.30 & 0.30 & 0.936 & $0.981(0.608-1.582)$ \\
\hline \multicolumn{5}{|c|}{ Over-dominant } \\
\hline $\mathrm{A} / \mathrm{A}-\mathrm{G} / \mathrm{G}$ & $44(64 \%)$ & $59(61.5 \%)$ & & 1.00 \\
\hline $\mathrm{A} / \mathrm{G}$ & $25(36 \%)$ & $37(38.5 \%)$ & 0.742 & $0.895(0.461-1.737)$ \\
\hline \multicolumn{5}{|l|}{ Recessive } \\
\hline $\mathrm{A} / \mathrm{A}-\mathrm{A} / \mathrm{G}$ & $61(88.4 \%)$ & $86(89.6 \%)$ & & 1.00 \\
\hline $\mathrm{G} / \mathrm{G}$ & $8(11.6 \%)$ & $10(10.4 \%)$ & 0.835 & $0.901(0.336-2.414)$ \\
\hline \multicolumn{5}{|l|}{ Dominant } \\
\hline $\mathrm{A} / \mathrm{A}$ & $36(52 \%)$ & $49(51 \%)$ & & 1.00 \\
\hline $\mathrm{A} / \mathrm{G}-\mathrm{G} / \mathrm{G}$ & $33(48 \%)$ & $47(49 \%)$ & 0.817 & $0.930(0.502-1.723)$ \\
\hline
\end{tabular}

\section{Discussion}

Resistance to Brucella has been mainly studied in mice and has shown that cytokines influence the outcome of the disease by regulation the immune response ${ }^{18}$. The capacity of cytokine production differs among individuals and correlates with the polymorphism in the cytokine gene promoters ${ }^{19}$. Although few studies in human, patients with acute brucellosis displayed a Th1-type response in contrast to those with chronic form who have diminished Th1 response in response to the Brucella specific antigens ${ }^{20}$. We have previously investigated the role of TNF- $\alpha-308 \mathrm{~A}$ andTNF- $\alpha-857 \mathrm{C} / \mathrm{T}$ polymorphism in susceptibility to human brucellosis by conducting genetic association studies based on case-control clinical studies. Our findings indicated an increased risk of TNF- $\alpha-308 \mathrm{~A}$ allele for human brucellosis consistent with the recessive genetic model of penetrance ${ }^{16}$. In this study, two transition polymorphisms located in the promoter of IFN- $\gamma$ R1 gene at nucleotides -56 (replacement of $\mathrm{C}$ by $\mathrm{T}$ ) and 611(replacement of A by $\mathrm{G}$ ) were selected for evaluation of their relation to susceptibility for human brucellosis. The IFN- $\gamma$ contributed to control of the infection. This has been demonstrated with Brucella abortus by showing that supplementing $\mathrm{BALB} / \mathrm{c}$ mice with recombinant IFN- $\gamma$ enhanced resistance resulting in a 10 -fold decrease in the number of bacteria at one week after infection. Also, it has been shown that depleting IFN- $\gamma$ by the administration of monoclonal antibodies which neutralized IFN- $\gamma$ resulted in a 10 -fold increase in the number of bacteria 1 week post-infection ${ }^{21}$. Polymorphisms affecting cytokines controlling the immune response against infectious diseases could be the potential markers of susceptibility and clinical outcome of different infectious diseases in humans ${ }^{22}$. In this study, both tested polymorphisms, IFN- $\gamma$ R1 - 56 C $>$ T polymorphism and IFN- $\gamma$ R1 - 611 $A>G$ polymorphism had no role in genetic susceptibility 
to human Brucellosis and the significant association was not present. There are various possible interpretations of these findings. The effects of IFN- $\gamma$ R1 polymorphisms on Brucella might be too small to be detected with this sample size, or might affect only a sub-phenotype of severe Brucella. It was likely that the genetic basis of susceptibility to Brucella is built upon many different protective genes, each individually resulting in small effects ${ }^{23}$. Similar results were reported by using other protective genes such as $\mathrm{TNF}-\alpha-857 \mathrm{C} / \mathrm{T}$ polymorphism against human brucellosis ${ }^{16}$. Furthermore, another study did not observe any significant associations between the IRF1 polymorphisms or haplotypes analyzed and susceptibility to severe disease in any of the study populations ${ }^{24}$.

Interestingly, screening of IFN- $\gamma$ R1 - $611 \mathrm{~A}>\mathrm{G}$ polymorphism by PCR-CTPP gave good genotyping results (Fig. 4 and Table 2). We have designed a PCR-CTPP method to be used for genotyping of IFN- $\gamma$ R1-611 A $>\mathrm{G}$ polymorphism (see materials and methods section). It is time-saving, easy to perform and inexpensive. It can be used for genotyping of most types of mutation ${ }^{17}$.

\section{Conclusion}

Interestingly, we have developed a PCR-CTPP system to be used for genotyping of IFN- $\gamma$ R1 - 611 A > G polymorphism. The PCR-CTPP is an accurate method for genotyping of SNPs. Moreover, it is time-saving, inexpensive and easy to perform. Both tested polymorphisms, IFN $-\gamma$ R1 - 56 C $>$ T polymorphism and IFN- $\gamma$ R1 - 611 $A>G$ polymorphism had no rule in genetic susceptibility to human Brucellosis in study population. Further insights could be gained by conducting fine mapping studies in multiple populations of larger sample size, where both phenotypes, Brucella load and disease severity, could be inspected against the same genetic background.

\section{Acknowledgement}

The authors wish to extend their gratitude to the Vice President for Post-graduate Studies and Research, Taif University for providing research facilities. This work is funded by the Deanship of Scientific Research, Taif University under the Fundamental Research Grant No.1 $5383 / 437 /$.

\section{Conflict of interest}

The authors declare that they have no conflict of interest.

\section{References}

1. Pappas G, Memish ZA. Brucellosis in the middle East: A persistent medical, socioeconomic and political issue. Journal of Chemotherapy. 2007; 19: 243-248. DOI: 10.1179/ joc.2007.19.3.243. PubMed .

2. Corbel MJ. Brucellosis: An overview. Emerging Infectious Diseases. 1997; 3: 213-221. DOI: 10.3201/eid0302.970219. 3. Aleissa Y. Brucellosis in Saudi Arabia; past, present and future. Annals of Saudi Medicine. 1999; 19: 403-405. PMID: 17277503

4. Hafez SM. The impact of uncontrolled animal importation and marketing on the prevalence of brucellosis in Saudi Arabia. Annals of Saudi Medicine. 1986; 6: 515-518. http:// eurekamag.com/research/001/710/001710043. php.

5. Ficht TA. Intracellular survival of Brucella: defining the link with persistence. Veterinary Microbiology. 2003; 92: 213-223. DOI: 10.1016/S0378-1135(02)00367-X.

6. Rodríguez-Zapata M, Matías MJ, Prieto A, Jonde MA, Monserrat J, Sánchez L, et al., Human brucellosis is characterized by an intense Th1 profile associated with a defective monocyte function. Infection and Immunity. 2010; 78: 3272-3279. DOI: 10.1128/IAI.01385-09.

7. Janeway Jr, CA, Medzhitov R. Innate immune recognition. Annual Review of Immunology 2002; 20: 197-216. 8. Murphy EA, Sathiyaseelan J, Parent MA, Zou B, Baldwin CL. Interferon-gamma is crucial for surviving a Brucella abortus infection in both resistant C57BL/6 and susceptible BALB/c mice. Immunology. 2001; 103: 511518. doi: 10.1046/j.1365-2567.2001.01258.x

9. Valente G, Ozmen L, Novelli F, Geuna M, Palestro G, Forni G, el al., Distribution of interferon-gamma receptor in human tissues. European Journal of Immunology. 1992; 22: 2403-2412. DOI: 10.1002/eji.1830220933

10. Leenen PJ, Canono BP, Drevets DA, Voerman JS, Campbell PA. TNF-alpha and IFN-gamma stimulate a macrophage precursor cell line to kill Listeria monocytogenes in a nitric oxide-independent manner. Journal of Immunology. 1994; 153: 5141-5147. PMID: 7525724

11. Boehm U, Klamp T, Groot M, Howard JC. Cellular responses to interferon-gamma. Annual Review of Immunology. 1997; 15: 749-795. DOI: 10.1146/annurev.immunol.15.1.749 
12. Ramana CV, Gil MP, Schreiber RD, Stark GR. Stat1-dependent and -independent pathways in IFN-gamma-dependent signaling. Trends in Immunology. 2002; 23: 96-101. 13. van Boxel-Dezaire AH,Stark GR. Cell type-specific signaling in response to interferon-gamma. Current Topics in Microbiology and Immunology. 2007; 316: 119-154. PMID: 17969446

14. van de Vosse E, Hoeve MA, Ottenhoff TH. Human genetics of intracellular infectious diseases: molecular and cellular immunity against mycobacteria and salmonellae. Lancet Infectious Diseases. 2004; 4: 739-749. 10.1016/ S1473-3099(04)01203-4

15. Zerbe CS, Holland SM. Disseminated histoplasmosis in persons with interferon-gamma receptor 1 deficiency. Clinical infectious diseases. 2005; 41: e38-41. DOI: 10.1086/432120

16. Ismael AB, Mergani A, Mostafa SA-H, Salim AM. Study the impact of T-helper 1 cytokine $(\mathrm{TNF}-\alpha)$ polymorphisms on susceptibility / resistance to Brucellosis in Makkah region. American Journal of Infectious Diseases. 2016; 12: 57-64 PubMed . DOI: 10.3844/ajidsp.2016.57.64.

17. Hamajima N, Saito T, Matsuo K, Kozaki K, Takahashi T, Tajima K. Polymerase chain reaction with confronting two-pair primers for polymorphism genotyping. Japanese Journal of Cancer Research. 2000; 91: 865-868 PubMed. 10.1111/j.1349-7006.2000.tb01026.x

18. Baldwin CL, Parent M. Fundamentals of host immune response against Brucella abortus: What the mouse model has revealed about control of infection. Veterinary
Microbiology. 2002; 90: 367-382. DOI: 10.1016/S03781135(02)00222-5

19. Ben-Ari Z., Mor E., Papo O., Kfir B., Sulkes, J., Tambur A.R., et al., Cytokine Gene Polymorphisms in Patients Infected With Hepatitis B Virus. American Journal of Gastroenterology. 2003, vol. 98, pp. 144-150. DOI: 10.1111/j.1572-0241.2003.07179.x

20. Giambartolomei GH, Delpino MV, Cahanovich ME, Wallach JC, Baldi PC, Velikovsky C.A., et al., Diminished production of $\mathrm{T}$ helper 1 cytokines correlates with $\mathrm{T}$ cell unresponsiveness to Brucella cytoplasmic proteins in chronic human brucellosis. Journal of Infectious Diseases. 2002; 186: 252-259. DOI: 10.1086/341449

21. Zhan Y, Cheers C. Endogenous gamma interferon mediates resistance to Brucella abortus infection. Infection and Immunity. 1993; 61: 4899-4901. DOI: 00199567/93/114899

22. Hajilooi M, Rafiei A, Reza M, Tajik N. Association of IL-1Ra gene polymorphism and susceptibility to human brucellosis. J comp. 2006; 68: 331-334 PubMed .

23. Mackinnon MJ, Mwangi TW, Snow RW, Marsh K, Williams TN. Heritability of malaria in Africa. PLOS Medicine. 2005; 2: e340.

24. Mangano VD, Clark TG, Auburn S, Campino S, Diakite M, Fry AE, et al., Lack of association of Interferon regulatory factor 1 with severe Malaria in affected child-parental trio studies across three African populations. PLOS ONE. 2009; 4: e4206. doi:10.1371/journal. pone.0004206. 